\title{
First observations of the oceanic migration of Japanese eel, from pop-up archival transmitting tags
}

\author{
Ryotaro Manabe $^{1, *}$, Jun Aoyama ${ }^{1}$, Kunihiro Watanabe ${ }^{2}$, Miho Kawai ${ }^{3}$, \\ Michael J. Miller ${ }^{1}$, Katsumi Tsukamoto ${ }^{1}$ \\ ${ }^{1}$ Atmosphere and Ocean Research Institute, University of Tokyo, 5-1-5 Kashiwanoha, Kashiwa, Chiba 277-8564, Japan \\ ${ }^{2}$ National Institute for Land and Infrastructure Management, Ministry of Land, Infrastructure, Transport and Tourism 1, \\ Asahi, Tsukuba City, Ibaraki 305-0804, Japan \\ ${ }^{3}$ Chiba Prefectural Fisheries Research Center Freshwater Station, 1390 Usuidai, Sakura, Chiba 285-0866, Japan
}

\begin{abstract}
Pop-up archival transmitting (PAT) tags were used for the first time to study the spawning migration of Japanese eels Anguilla japonica. Three silver eels $(70$ to $98 \mathrm{~cm}$ ) tagged with PAT tags were released in January 2008 and 6 were released in November 2008 at 2 different locations near the Kuroshio Current, along the southern part of Japan. The tags were preprogrammed to ascend 7 to $90 \mathrm{~d}$ after release and data on their pop-up positions, eel swimming depths and water temperatures experienced were retrieved from all but one tag via Argos satellites. Most tags ascended in or near the Kuroshio Current up to $1400 \mathrm{~km}$ from the eels' release points, and the longest tracking period of $39 \mathrm{~d}$ suggested eastward movements of migrating eels. Two eels tracked for about a month or more showed clear diel vertical migrations (DVMs), predominantly swimming between depths of about 100 to $500 \mathrm{~m}$ at night and 500 to $800 \mathrm{~m}$ in the daytime, and eventually down to $1000 \mathrm{~m}$ depth for one eel. All eels over deep water reached similar minimum temperature ranges during the daytime, even if the depth of that range changed, suggesting they were selecting a preferred minimum temperature rather than a particular depth. Calculated straight-line swimming speeds were faster than those determined in previous reports that included larger-sized eels, suggesting swimming tracks along the Kuroshio Current were faster as a result of the strong current. Extensive DVMs may be performed by A. japonica and other anguillid eels not only for predator avoidance, but also possibly to control gonad maturation by swimming at shallower depths at night where water temperatures are warmer and then moving to deeper layers during the daytime where water temperatures are cooler.
\end{abstract}

KEY WORDS: Japanese eel · Spawning migration - Diel vertical migration - Pop-up archival transmitting tag $\cdot$ Kuroshio Current $\cdot$ Gonad maturation $\cdot$ Predation

\section{INTRODUCTION}

Japanese eels Anguilla japonica and other anguillids are famous for their long spawning migrations to the open ocean after starting their reproductive maturation from autumn to winter (Schmidt 1922, Tsuka- moto 1992, 2009, Tesch 2003). Long-term sampling efforts in the open ocean have recently collected eggs, newly hatched larvae, and mature adults, which has established the exact location of $A$. japonica spawning sites in the waters around the southern part of the West Mariana Ridge (Tsukamoto et al. 
2003, 2011, Tsukamoto 2006, Chow et al. 2009). These studies provided significant information about the spawning ecology of $A$. japonica, but the characteristics of their migrations to the spawning area from their growth habitat, even their route and swimming depth, are still entirely unknown because migrating Japanese eels have never been collected far offshore in the open ocean (Tsukamoto 2009).

A number of tracking studies using acoustic tags, have examined the migration behavior of anguillid eels in the ocean (Tesch 1978, 1989, Aoyama et al. 1999, 2002, McCleave \& Arnold 1999). The tracking durations of the studies were too short (ca. $1 \mathrm{wk}$ ) to cover the whole oceanic migration period, because acoustic tracking requires that eels be followed sufficiently closely to receive the acoustic signal, and also because often only small boats were used. Acoustic tracking studies (Aoyama et al. 1999, 2002) have provided no clear information on the migratory behavior of Anguilla japonica, but Tsukamoto (2009) examined several hypotheses about their migration routes. One possibility is that the eels use a direct compass course towards the spawning area by first traversing beneath the strong Kuroshio Current (Matsui 1972). Other possibilities are that the eels follow the surface currents, in which one route first follows the northeastward flow of the Kuroshio Current to the east of Japan and then a southward branch current along the Izu-Bonin Arc (Tsukamoto 1994), while another route backtracks upstream against the Kuroshio Current that transports eel larvae to East Asia (Yokose 2008). However, our present knowledge is insufficient to evaluate these possibilities.

The recent development of pop-up archival transmitting (PAT) tags provides a means of collecting long periods of data on the movement of fishes. The tags collect data on the ambient water temperature and swimming depth of the fish, then detach from the fish at pre-programmed times and ascend to the surface to transmit collected data to satellites. This makes it possible to track the oceanic migrations of fish and describe their thermal and depth preferences over long periods (e.g. Block et al. 1998, 2005, Weng et al. 2007). Jellyman \& Tsukamoto $(2002,2005,2010)$ were the first to use PAT tags for studying the migration of anguillid eels in the ocean. They successfully tracked the spawning migration of a New Zealand eel species, Anguilla dieffenbachii, for up to $161 \mathrm{~d}$. Aarestrup et al. (2009) recently collected up to $126 \mathrm{~d}$ of data about the spawning migration of the European eel A. anguilla.
To study the spawning migration of Anguilla japonica, we conducted tracking studies using PAT tags in January and November 2008. In this paper, we present the first data on the offshore migratory behaviors of $A$. japonica as a result of these studies.

\section{MATERIALS AND METHODS}

\section{Eels}

January 2008

Approximately 20 Anguilla japonica were caught by dip net on 7 January 2008 as they swam near the surface off Koshiki Island, near Kyushu Island of southern Japan (Fig. 1). These eels, which can be caught at the surface at night by using lights and dipnets, are thought to be migrating silver eels (Sasai et al. 2001, Kotake et al. 2003). After capture, the eels were kept in a tank $(100 \times 100 \mathrm{~cm} \times 50 \mathrm{~cm}$ deep $)$ with seawater $\left(17\right.$ to $\left.19^{\circ} \mathrm{C}\right)$ on the FV 'Mokusei' for about $1 \mathrm{~d}$ before being released. The 3 largest eels (Eels 1 to 3 , Table 1) were chosen for tagging. They were individually removed from the holding tank, anaesthetized in a separate tank with eugenol $(2 \%)$ and then a PAT tag was attached as described ('Tag attachment') below. Tagged eels were retained in seawater $\left(19^{\circ} \mathrm{C}\right)$ in a plastic bag $(110 \times 85 \mathrm{~cm})$ until they recovered from anesthetization, and then they were individually released from the FV 'Mokusei' in water about $700 \mathrm{~m}$ deep off Koshiki Island (Fig. 1) in the early evening beginning at 19:30 h on 8 January 2008.

November 2008

The 5 largest among 10 migrating silver eels collected in October 2008 by commercial fishers using set nets or an eel sickle (a hook-like device on a pole used for grappling an eel out of the mud) in the estuary of the Tone River, and a migrating silver eel caught in November 2008 by set nets in Mikawa Bay (Fig. 2), were used for tagging (Eels 4 to 9, Table 1). Eels were transported in large plastic bags then were held in a large container $(140 \times 140 \mathrm{~cm} \times 60 \mathrm{~cm}$ deep $)$ with running seawater at $25^{\circ} \mathrm{C}$ on the RV 'Tansei Maru'. Before tagging, the eels were anaesthetized with $2 \%$ eugenol as in January. Tagged eels were retained in plastic bags containing seawater $\left(25^{\circ} \mathrm{C}\right)$ until they recovered from anesthetization and then were released. Five of the eels were released from the RV 'Tansei Maru' in water about $1000 \mathrm{~m}$ deep off 


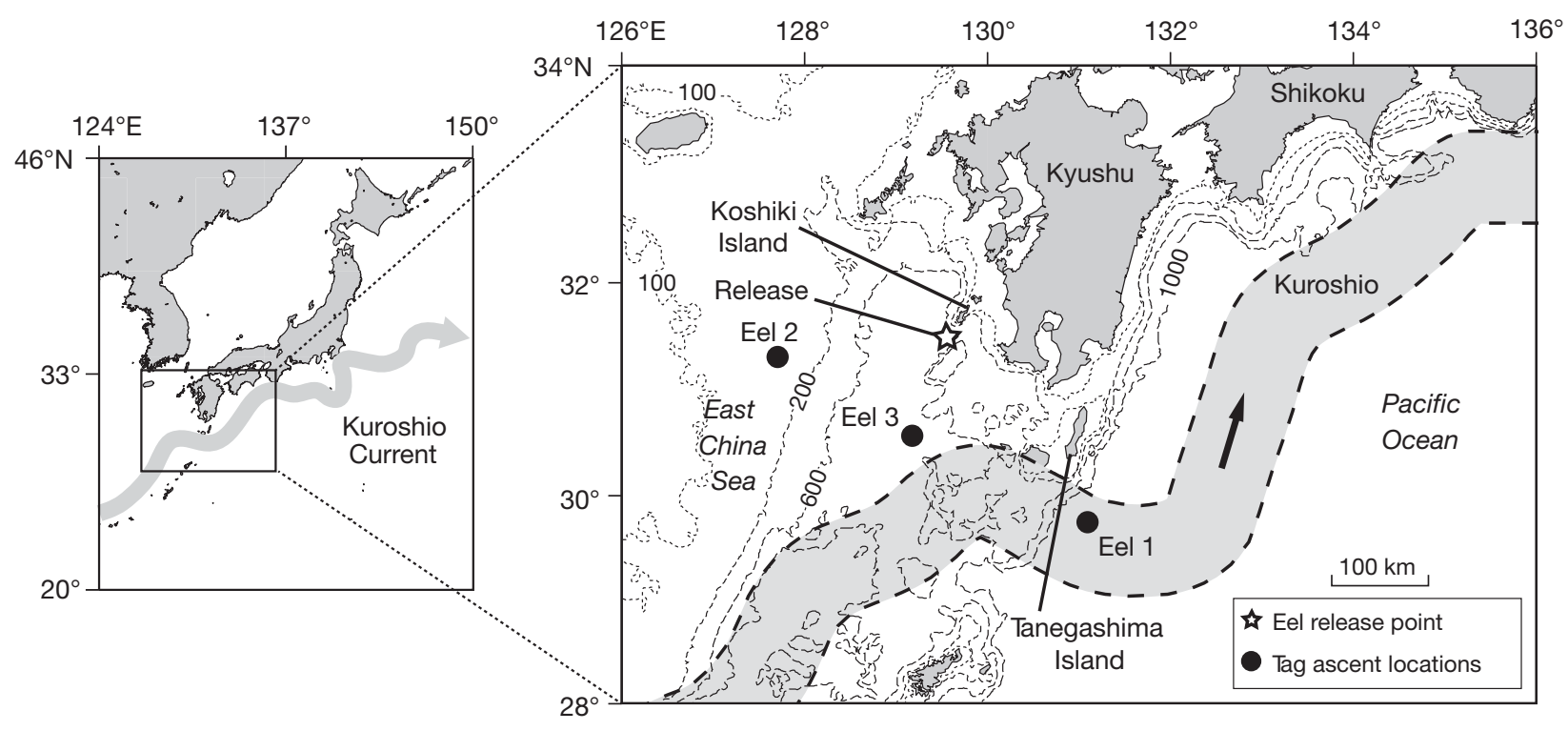

Fig. 1. Anguilla japonica. Eel release points and ascent locations of the PAT tags in January 2008. The CNES/CLS Aviso/Altimetry project (www.aviso.oceanobs.com, Ducet et al. 2000) was used for drawing the estimated location of the Kuroshio Current on 24 January 2008. Bathymetry data were obtained from the SATELLITE GEODESY

Tanegashima Island to the south of Kyushu at night at 01:00 h on 21 November 2008 and 1 eel (Eel 9) was released in the same area after sunset at $18: 40 \mathrm{~h}$ on 26 November 2008. A CTD profile was made at the release site on 21 November 2008 after the eels were released. The hydrographic structure at this location consisted of a mixed layer of warm water $\left(25.5^{\circ} \mathrm{C}\right)$ in the upper $52 \mathrm{~m}$ above the thermocline, and then temperatures decreased gradually to $10.1^{\circ} \mathrm{C}$ at $330 \mathrm{~m}$ and to $4.3^{\circ} \mathrm{C}$ at $650 \mathrm{~m}$, followed by a slower decrease to $3.4^{\circ} \mathrm{C}$ at $1000 \mathrm{~m}$. The salinity ranged between 34.1 and 34.7 in the upper $200 \mathrm{~m}$, but remained between 34.3 and 34.4 from 250 to $1000 \mathrm{~m}$.

\section{Tag setup}

January 2008

The PAT tags (Wildlife Computers) used in the study weighed $75 \mathrm{~g}$, were $175 \mathrm{~mm}$ in length (excluding the antenna) and were pressure tested to a depth of $2000 \mathrm{~m}$. The 3 tags were pre-programmed to record water temperature (resolution $\pm 0.05^{\circ} \mathrm{C}$ ), depth (resolution $\pm 0.5 \mathrm{~m}$ ) and light intensity every $2 \mathrm{~s}$ and were set to ascend at 7,30 and $90 \mathrm{~d}$ (Eels 1, 2 and 3, respectively) after deployment. All tags had a premature release mechanism that would release the

Table 1. Anguilla japonica. Biological and collection site data, tag programming and duration of data acquisition for the Japanese eels that were tagged. Depth and temperature were summarized into 24 or $6 \mathrm{~h}$ histograms to reduce data transmission size. TL: total length; BW: body weight

\begin{tabular}{|c|c|c|c|c|c|c|c|c|}
\hline \multirow{2}{*}{$\begin{array}{l}\text { Eel } \\
\text { no. }\end{array}$} & \multicolumn{5}{|c|}{- Eel -} & \multirow[b]{2}{*}{$\begin{array}{l}\text { Summarizing } \\
\text { histogram (h) }\end{array}$} & \multirow{2}{*}{$\begin{array}{c}\text { PAT- } \\
\text { Scheduled } \\
\text { duration (d) }\end{array}$} & \multirow[b]{2}{*}{$\begin{array}{c}\text { Actual } \\
\text { duration }(\mathrm{d})\end{array}$} \\
\hline & $\begin{array}{c}\mathrm{TL} \\
(\mathrm{cm})\end{array}$ & $\begin{array}{l}\text { BW } \\
(\mathrm{kg})\end{array}$ & $\begin{array}{l}\text { Silver } \\
\text { index }\end{array}$ & $\begin{array}{c}\text { Release } \\
\text { day (2008) }\end{array}$ & $\begin{array}{l}\text { Original capture } \\
\text { Month, Location }\end{array}$ & & & \\
\hline 1 & 70.0 & 0.62 & S1 & 8 Jan & Jan 2008, Koshiki Island & 24 & 7 & 7 \\
\hline 2 & 80.0 & 1.27 & $\mathrm{~S} 2$ & 8 Jan & Jan 2008, Koshiki Island & 24 & 30 & 15 \\
\hline 3 & 88.7 & 1.58 & $\mathrm{~S} 2$ & 8 Jan & Jan 2008, Koshiki Island & 24 & 90 & 12 \\
\hline 4 & 90.6 & 1.30 & $\mathrm{~S} 2$ & $21 \mathrm{Nov}$ & Oct 2008, Tone River & 6 & 14 & 1 \\
\hline 5 & 89.9 & 1.18 & S1 & $21 \mathrm{Nov}$ & Oct 2008, Tone River & 6 & 28 & 2 \\
\hline 6 & 92.4 & 1.52 & $\mathrm{~S} 2$ & $21 \mathrm{Nov}$ & Oct 2008, Tone River & 6 & 56 & 29 \\
\hline 7 & 89.4 & 1.36 & S1 & $21 \mathrm{Nov}$ & Oct 2008, Tone Rive & 6 & 84 & $3 r$ \\
\hline 8 & 96.0 & 1.50 & $\mathrm{~S} 2$ & $21 \mathrm{Nov}$ & Oct 2008, Tone River & 6 & 84 & 39 \\
\hline 9 & 97.7 & 1.52 & $\mathrm{~S} 2$ & $26 \mathrm{Nov}$ & Nov 2008, Mikawa Bay & 6 & 7 & Unknown \\
\hline
\end{tabular}




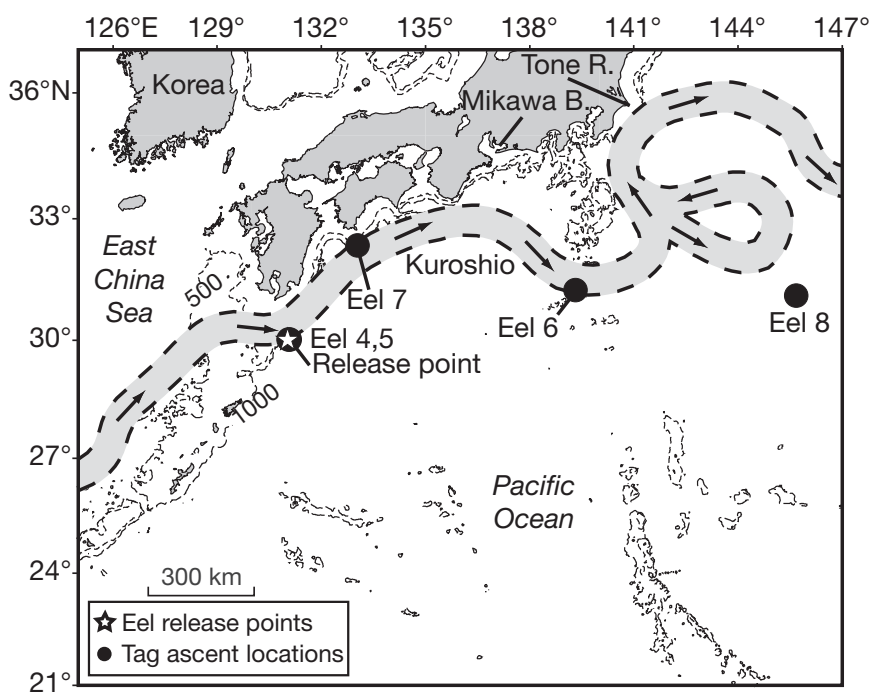

Fig. 2. Anguilla japonica. Eel release points and ascent locations of PAT tags in November 2008. Sources of information for the map are the same as in Fig. 1. The estimated location of the Kuroshio Current is for 21 December 2008. Tone R. = Tone River, Mikawa B. = Mikawa Bay

tag after $96 \mathrm{~h}(4 \mathrm{~d})$ at a constant depth $( \pm 2.5 \mathrm{~m})$ on the assumption the eel was dead. Depth and water temperature data were summarized into $24 \mathrm{~h}$ histograms to minimize the data size to be transmitted via satellite. The depth data were sorted into 12 bins following the prescribed intervals (Bin 1: $<1 \mathrm{~m}_{\text {; }}$ Bin 2: 1 to $9 \mathrm{~m}_{\text {; }}$ Bin 3: 10 to $49 \mathrm{~m}_{\text {; }}$ Bin 4: 50 to $99 \mathrm{~m}_{\text {; }}$ Bins 5 to 12 were at $100 \mathrm{~m}$ intervals ranging from 100 to $199 \mathrm{~m}$ up to 800 to $899 \mathrm{~m}$ ) and the water temperature data were divided into 9 bins (Bin 1: 3 to $5.9^{\circ} \mathrm{C}$, Bins 2 to 9 were at $3.0^{\circ} \mathrm{C}$ intervals ranging from 6.0 to $8.9^{\circ} \mathrm{C}$ up to 27.0 to $29.9^{\circ} \mathrm{C}$ ).

\section{November 2008}

The settings of the tags used in November were the same as those in January, except that the 6 tags were pre-programmed to ascend from 7 to $84 \mathrm{~d}$ after deployment (Table 1) and to prematurely release after $72 \mathrm{~h}$ at a constant depth. Depth and water temperature data were summarized into shorter $6 \mathrm{~h}$ histograms with depth in 14 bins (Bin 1: $<1 \mathrm{~m}_{\text {; }}$ Bin 2: 1 to $9 \mathrm{~m}_{;}$Bin 3: 10 to $49 \mathrm{~m}_{i}$ Bin 4: 50 to $99 \mathrm{~m}_{\text {; }}$ Bins 5 to 13 were at $100 \mathrm{~m}$ intervals ranging from 100 to $199 \mathrm{~m}$ up to 900 to $999 \mathrm{~m}$, Bin 14: >1000 m) and temperature in 13 bins (Bin 1: 2.0 to $3.9^{\circ} \mathrm{C}$; Bins 2 to 13 were at $2.0^{\circ} \mathrm{C}$ intervals ranging from 4.0 to $5.9^{\circ} \mathrm{C}$ up to 26.0 to $27.9^{\circ} \mathrm{C}$; Bin $14:>28^{\circ} \mathrm{C}$ ).

\section{Tag attachment}

January 2008

Eels were anaesthetized and their total lengths, body weights and silvering indices (see Okamura et al. 2007) were measured (Table 1). Surgical tagging was carried out following the method of Jellyman \& Tsukamoto (2002) with some slight modifications. Two $60 \mathrm{~cm}$ long monofilament lines $(18.2 \mathrm{~kg}$ breaking strain) were inserted into a $5 \mathrm{~cm}$ length of nylon tubing that protected the monofilament lines from being rubbed by the eye of the tag. They were threaded through the eye of the tag and knotted to form a tight loop. A small pressure-operated plunger (Wildlife Computers) that severs the line when the depth exceeds $1800 \mathrm{~m}$ was pushed up the lines to the base of this loop and then a brass crimp was slid up the lines to the base of the plunger (see Fig. 3). The crimp was lightly squeezed to ensure it held the tube securely in place.

For attaching the tag to the eel, a curved surgical needle that forms $3 / 8$ of a circle $(9.3 \mathrm{~cm})$ with one end of the monofilament line attached was inserted through the dorsal side of the lateral musculature $\sim 3 \mathrm{~cm}$ posterior to the origin of the dorsal fin and pushed upward to emerge on the other side of the eel. A similar technique was used at a second place slightly farther back. The tag was then secured against the back of the eel by gently pulling on both emerging lengths of nylon (Fig. 3). Rubber and plastic discs were then threaded onto the emerging lengths of nylon, which were pulled tight, and the

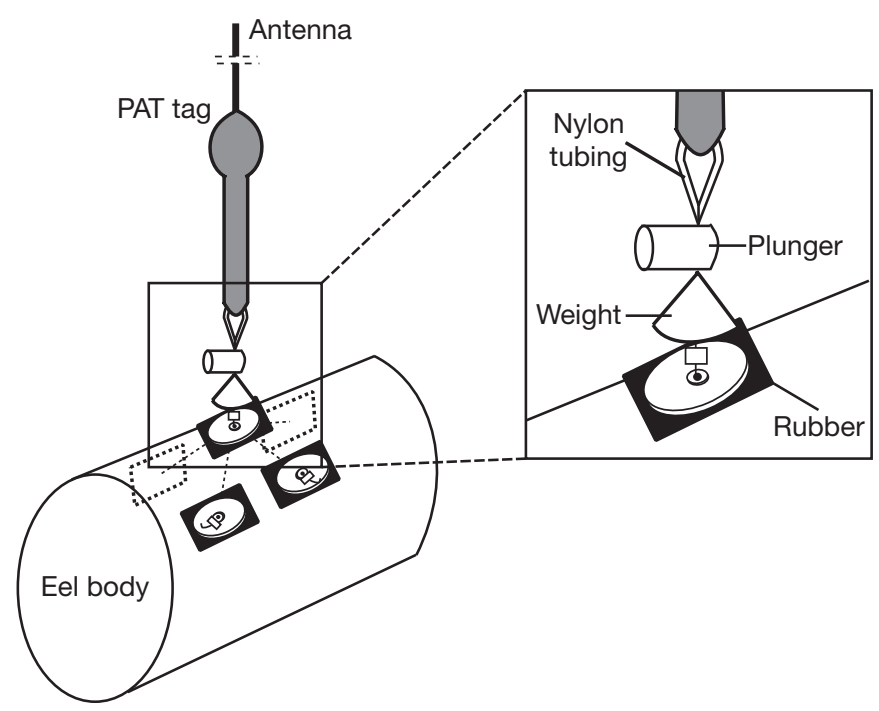

Fig. 3. Tag attachment method used on the 5 eels in November 2008 
positions of the discs were then secured with brass crimps.

The tag attachment method had been previously tested in the laboratory during a 2.5 mo period with 3 Anguilla japonica silver eels (67.5 to $75.2 \mathrm{~cm} \mathrm{TL}$ ) that were tagged with dummy PAT tags $(75 \mathrm{~g}, 175 \mathrm{~mm}$ in length excluding the antenna) and then held in a tank $(400 \times 100 \mathrm{~cm} \times 55$ to $70 \mathrm{~cm}$ deep) filled with seawater $\left(12.0\right.$ to $\left.20.0^{\circ} \mathrm{C}\right)$. These eels showed no apparent ill effects from tagging and the tags remained secure on the eels, although the eels had a limited ability to swim inside the tank.

November 2008

The tagging procedure was modified from that used in January by attaching a weight $(14 \mathrm{~g})$ under the small pressure-operated plunger to help the tag remain at neutral buoyancy during the tracking period (Fig. 3).

\section{RESULTS}

\section{Ascent location and tracking period}

January 2008

The PAT tags of the 3 Japanese eels released in January ascended within a month at 3 different locations (Fig. 1). The tag of Eel 1 ascended to the surface within the Kuroshio Current to the south of Tanegashima Island on 15 January as scheduled ( $7 \mathrm{~d}$ after release). The tag of Eel 2 ascended much farther to the west in the northern East China Sea on 27 January (19 d) and the tag of Eel 3 was found at an intermediate location $130 \mathrm{~km}$ offshore of Koshiki Island on 24 January (16 d, Fig. 1). The tags of Eels 2 and 3 were detached before the scheduled dates by the premature release system, because they floated for $4 \mathrm{~d}$ on the surface with no change in their depth.

\section{November 2008}

A variety of results were obtained from the tags of the 6 eels released in November. No data were received from the tag of Eel 9 for an undetermined reason. The 5 remaining tags ascended before their scheduled dates, released by the detaching system at depths ranging from 1000 to $1912 \mathrm{~m}$ (Table 1). Although the tags of Eels 4 and 5 ascended near the release point within a few days of release, the tag from Eel 6 ascended offshore farther to the east along the Kuroshio Current ( $31 \mathrm{~d}$ after release, $820 \mathrm{~km}$ from the release point) on 22 December 2008. The tag of Eel 7 ascended near the western edge of the Kuroshio Current offshore of the continental shelf of Shikoku Island to the east of Kyushu ( $6 \mathrm{~d}, 330 \mathrm{~km})$ on 27 November 2008, and the tag from Eel 8 ascended east and south of the Kuroshio Current in the Pacific Ocean (41 d, $1400 \mathrm{~km}$ ) on 1 January 2009 (Fig. 2).

\section{Swimming depth and water temperature}

January 2008

All 3 eels experienced wide depth and temperature ranges during their tracking periods. The maximum swimming depths for Eels 1 (376 m, Day 1), 2 (888 m, Day 3) and 3 (552 m, Day 3) were observed within $3 \mathrm{~d}$ after deployment, but Eel 1 ( $70 \mathrm{~cm} \mathrm{TL}$ ) showed a very different depth distribution pattern (mostly swimming at shallow depths $<200 \mathrm{~m}$ ) compared with Eel 2 $(80 \mathrm{~cm} \mathrm{TL})$ and Eel $3(88 \mathrm{~cm} \mathrm{TL})$, both of which swam at bimodal depths between 0 and $199 \mathrm{~m}$ and between 500 and $599 \mathrm{~m}$ during those first $3 \mathrm{~d}$ (Fig. 4). The data obtained after $3 \mathrm{~d}$ showed 3 different patterns of depth distribution. Eel 1 always swam in near-surface waters ( 0 to $144 \mathrm{~m}$ and 20.2 to $17.2^{\circ} \mathrm{C}$ ) in a pattern similar to that during Days 2 and 3. Eel 2 swam between depths of 0 to $648 \mathrm{~m}$ and temperatures of 21.0 to $6.0^{\circ} \mathrm{C}$, then suddenly, at $9 \mathrm{~d}$ after release, shifted to shallower depths $(<368 \mathrm{~m})$ and warmer minimum temperatures $\left(23.9\right.$ to $\left.15.0^{\circ} \mathrm{C}\right)$. Eel 3 abruptly changed, on Day 4, to swimming at depths of between 0 and $312 \mathrm{~m}$ and temperatures of 26.9 to $15.0^{\circ} \mathrm{C}$ (Figs. $4 \& 5$ ). The sudden change in depth and temperature ranges for Eel 2 probably corresponds with the eel moving over the shallower water on the continental shelf and slope in the East China Sea (Fig. 1). Some data series of depth and temperature in January and also November were slightly discontinuous because of problems receiving the data from the ARGOS satellites.

November 2008

The eels tagged and released in November also experienced a wide range of depths and water temperatures. Although 3 of the 5 eels whose PAT tags successfully transmitted data did not provide much useful information, Eel 6 (92 cm TL) and Eel 8 (96 cm 

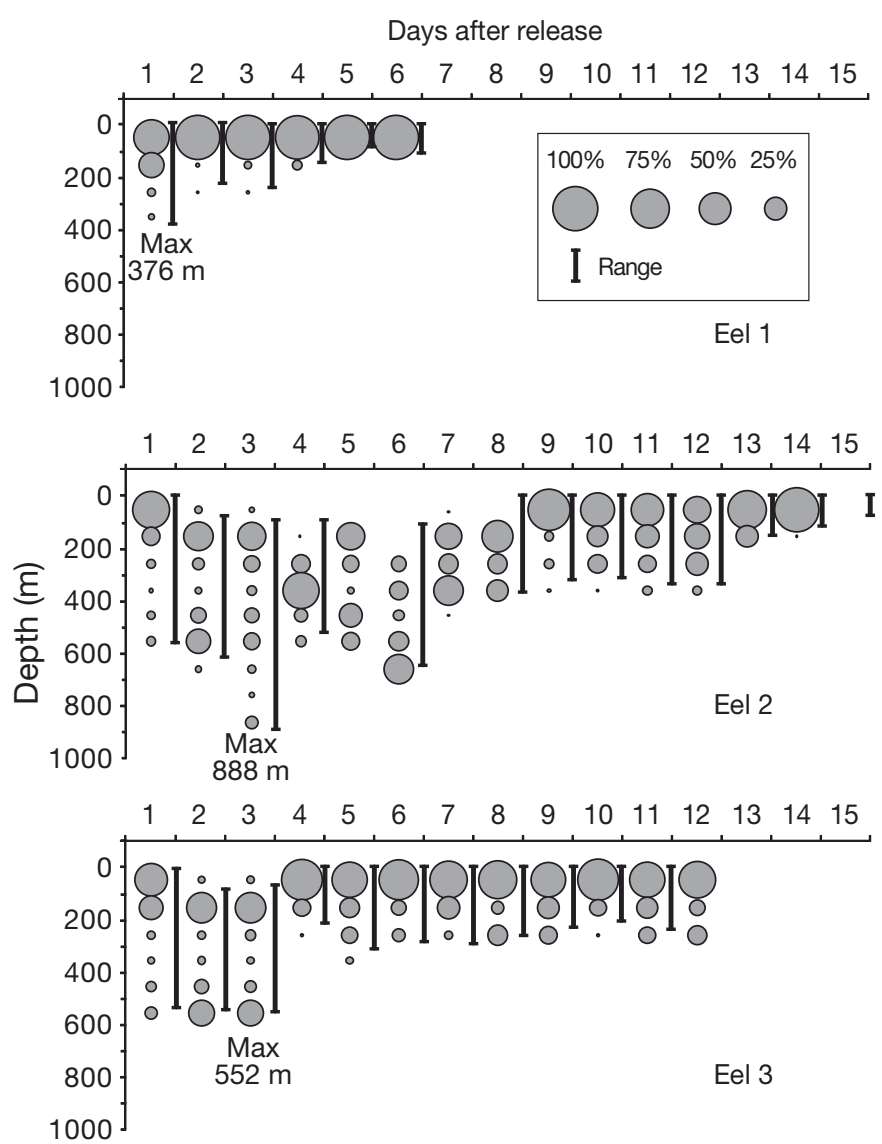

Fig. 4. Anguilla japonica. Percentage of time spent by 3 eels at various depths in January 2008. Each bar indicates the total range of swimming depths and the circle sizes correspond to the percentages of time at each depth

TL) showed a clear pattern of diel vertical migration (DVM) over the 29 and $39 \mathrm{~d}$ they were followed, respectively (Figs. 6 \& 7). At night Eel 6 predominantly swam between 100 and $199 \mathrm{~m}$ at temperatures between 21.9 and $16.0^{\circ} \mathrm{C}$ until about $11 \mathrm{~d}$ after release. Later, the swimming depth shifted progressively deeper and finally tended to range widely between 100 and $499 \mathrm{~m}$ in the cooler water temperatures between 19.9 and $14.0^{\circ} \mathrm{C}$ (Figs. 6 \& 7). In contrast, during the day Eel 6 frequently swam between 400 and $599 \mathrm{~m}$ until $5 \mathrm{~d}$ after release and later progressively shifted to deeper depths (Fig. 6). Finally it tended to range between 500 and $899 \mathrm{~m}$, and reached depths of greater than $1000 \mathrm{~m}$ during the last $8 \mathrm{~d}$ (Fig. 6). Although both the day and night depths of this eel became deeper, the water temperatures it experienced in the daytime $\left(9.9\right.$ to $\left.4.0^{\circ} \mathrm{C}\right)$ and nighttime $(22.0$ to $14.0^{\circ} \mathrm{C}$ ) did not change as much (Fig. 7). Eel 8 showed a similar pattern of DVM, with swimming depths of 100 to $499 \mathrm{~m}$ and temperatures of 19.9 to $14.0^{\circ} \mathrm{C}$ during the night and swimming depths of 500 to $799 \mathrm{~m}$ and temperatures of 9.9 to $4.0^{\circ} \mathrm{C}$ during the day (Figs. 6 \& 7). Eel 8 did not show a clear pattern of gradual change of its swimming depths as Eel 6 did, although there were minor variations in the swimming depths and temperatures it experienced. It did, however, experience similar water temperatures during both night and day as did Eel 6 .

The 3 other eels whose PAT tags successfully transmitted data in November did not provide much useful information because they either directly went to the bottom or only swam for $4 \mathrm{~d}$ before going to the bottom. Eels 4 (91 cm TL) and 5 (90 cm TL) directly dove down to 1344 and $1352 \mathrm{~m}$, respectively, and experienced minimum water temperatures of $2.8^{\circ} \mathrm{C}$ after release. They stayed at these depths until the premature release system was activated. Eel $7(89 \mathrm{~cm}$ TL) did not exhibit DVM and swam between surface and $499 \mathrm{~m}$ during day and night, and experienced water temperatures between 8.0 and $25.9^{\circ} \mathrm{C}$ for $4 \mathrm{~d}$.

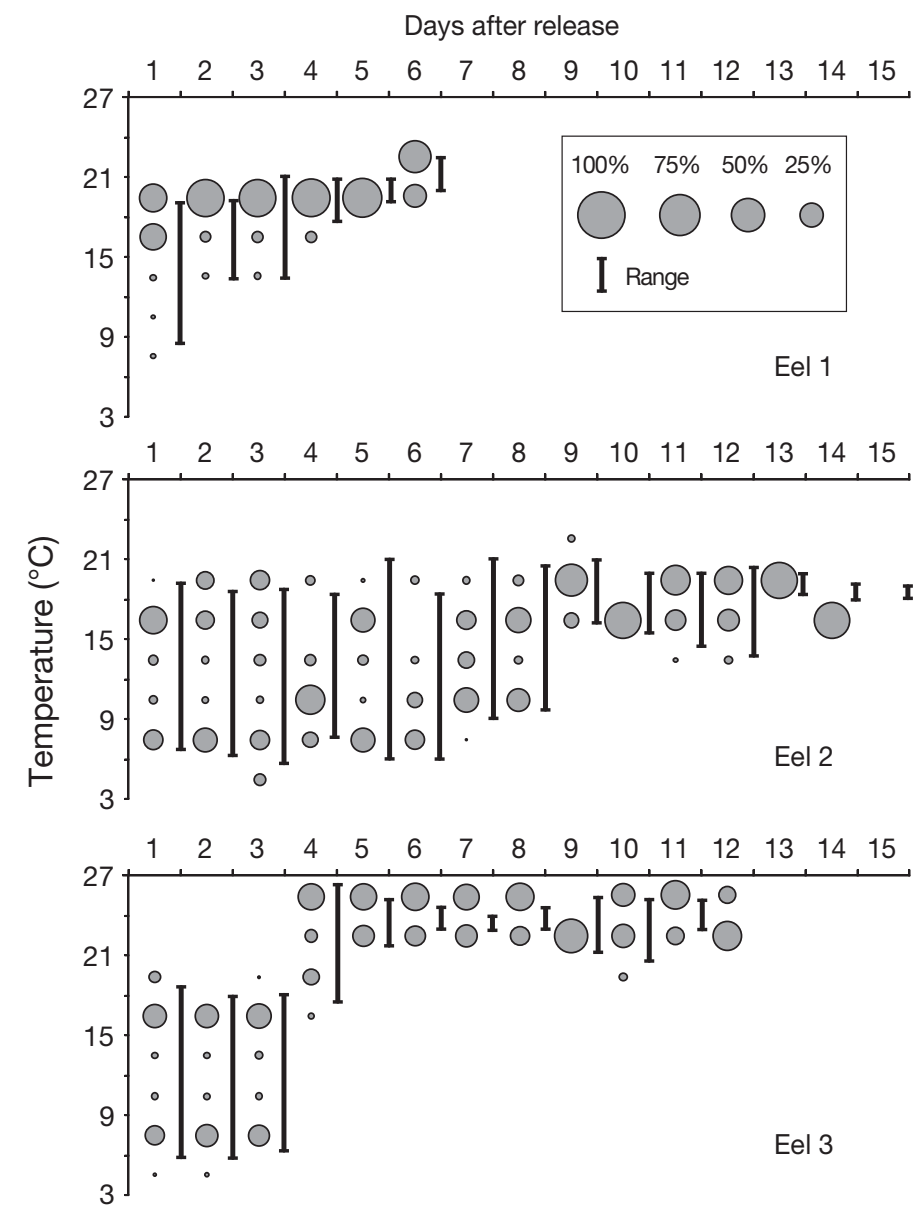

Fig. 5. Anguilla japonica. Percentage of time spent by 3 eels at various water temperatures in January 2008. Each bar indicates the total range of swimming depths and the circle sizes correspond to the percentages of time at each depth 


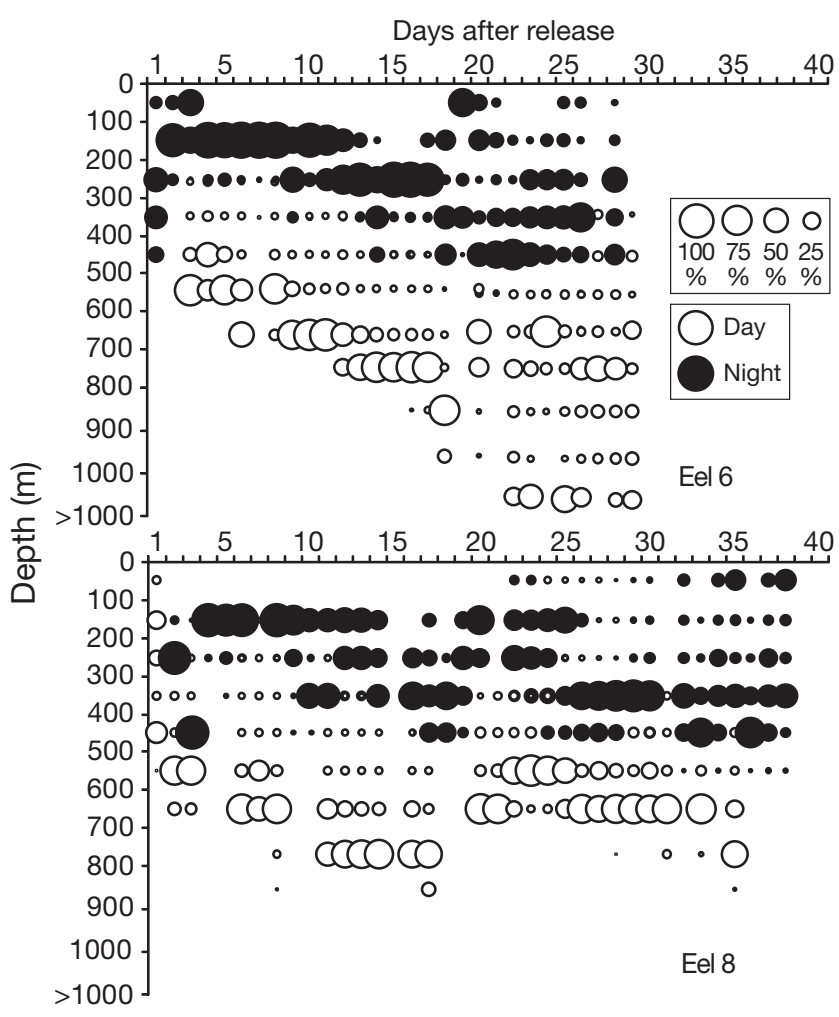

Fig. 6. Anguilla japonica. Percentage of time spent by Eels 6 and 8 at various depths in November 2008, shown by the circle sizes

After $4 \mathrm{~d}$, this eel also dove to a depth of $1000 \mathrm{~m}$ and experienced minimum water temperatures of $3.4^{\circ} \mathrm{C}$ until the tag was prematurely released.

\section{Horizontal movement and estimation of swimming speed}

All but 3 eels tagged in the present study showed eastward movements after their release that mostly corresponded to the flow direction of the Kuroshio Current. PAT tags continuously measure light intensity to enable the position of the fish to be estimated by the WC-GPE computer program (Wildlife Computers). However, the daytime swimming depths of our Anguilla japonica were too deep to measure light intensity $(>400 \mathrm{~m})$, so their horizontal swimming courses could not be determined.

The estimated swimming speeds of many of the eels were fast and appeared to be affected by the strong speed of the Kuroshio Current. The average swimming speeds estimated in a simple straight line from the release point to the pop-up locations for Eels 1, 6 and 8 that moved the furthest (straight line distances 245-1000 km) were 35.0, 28.3 and $35.9 \mathrm{~km} \mathrm{~d}^{-1}$, respectively. If these eels swam along the Kuroshio Current, their estimated travel distances would be $\sim 290,1100$ and $1600 \mathrm{~km}$, respectively, but the speed of the Kuroshio Current $\left(80 \mathrm{~cm} \mathrm{~s}^{-1}\right.$ at 0 to $100 \mathrm{~m}$ depth, center of the current in the East China Sea: Ichikawa \& Beardsley [2002]; 40 to $100 \mathrm{~cm} \mathrm{~s}^{-1}$ at 200 to $400 \mathrm{~m}$ depth, center to the southern part of the current offshore south of Japan, and $30 \mathrm{~cm} \mathrm{~s}^{-1}$ at 600 to $700 \mathrm{~m}$ depth in the same area: Sekine [2002]) could greatly increase their rate of movement. Assuming that the eels were swimming in the same direction as the current and were transported by the current during both the night and day, the swimming speeds of Eels 1, 6 and 8 could have been in the range of about $6.9 \mathrm{~km} \mathrm{~d}^{-1}, 3.4$ to $13.9 \mathrm{~km} \mathrm{~d}^{-1}$ and 2.2 to $15.0 \mathrm{~km} \mathrm{~d}^{-1}$, respectively, depending on how much time was spent in parts of the current with different speeds. The straight line swimming speeds of the other eels that moved away from the release points (Eels 4, 5 and 7) ranged from 5.6 to $82.0 \mathrm{~km} \mathrm{~d}^{-1}$. Assuming that Eel 7 was transported by the center of the current during day and night owing to its shallow swimming depths, the swimming speed of Eel 7 could have been about 4.4 to $12.8 \mathrm{~km} \mathrm{~d}^{-1}$.

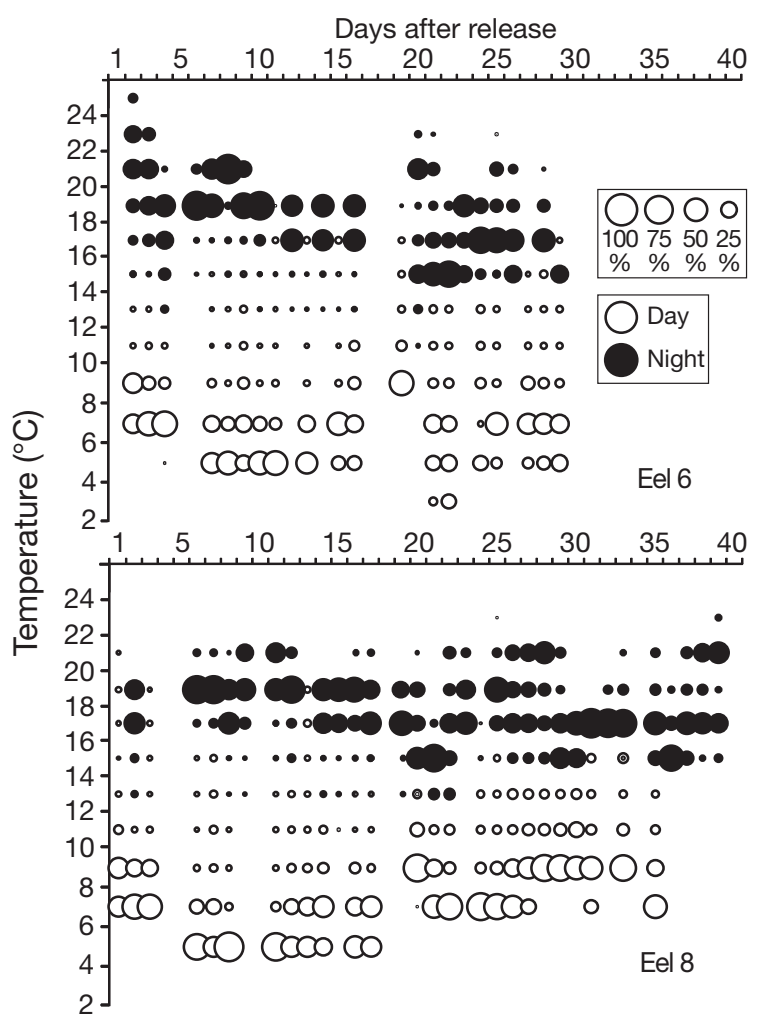

Fig. 7. Anguilla japonica. Percentage of time spent by Eels 6 and 8 at various water temperatures in November 2008, shown by the circle sizes 


\section{DISCUSSION}

\section{Migration route and speed}

Our understanding of the migration route of the tagged Anguilla japonica was complicated by several factors, including the effects of the tags on the eels, transport by the strong Kuroshio Current and the lack of geolocation data that was caused by their deep daytime swimming depths. The tracks of Eels 6 and 8 could not be measured directly because of the lack of geolocation data, but their estimated swimming speeds and temperature-depth relationships provided clues about their tracks. Previous PAT tag studies provided estimated average swimming speeds of $13.8 \mathrm{~km} \mathrm{~d}^{-1}$ for $A$. anguilla (87 to $106 \mathrm{~cm}$ $\mathrm{TL})$ and $18.3 \mathrm{~km} \mathrm{~d}^{-1}$ for the larger $A$. dieffenbachii (128 to $145 \mathrm{~cm}$ TL) (Jellyman \& Tsukamoto 2005, Aarestrup et al. 2009). The estimated swimming speeds for Eels 6 and 8 ( 89 and $96 \mathrm{~cm} \mathrm{TL}$ ) based on straight line tracks between the release and recovery locations seem to be overestimated because the $A$. japonica were smaller or similar in size to the eels used in the previous studies. Thus, the 3 A. japonica may have swum within the Kuroshio Current, resulting in estimated swimming speeds of 2.2 to $15.1 \mathrm{~km}$ $\mathrm{d}^{-1}$. The $15.1 \mathrm{~km} \mathrm{~d}^{-1}$ estimate compares well with those for the other species as do the swimming speeds for Eels 1 and 7, assuming that they also swam within the Kuroshio Current at least part of the time.

The data obtained in November suggest that the tagged eels did not attempt to leave the Kuroshio Current to immediately begin to swim in a straightline direction to the spawning area, but there is not enough evidence to conclude this for certain. Eel 6 appeared to slowly move across the Kuroshio Current over time, as discussed below, but there is no evidence that it moved out of the Kuroshio Current flow. Tsukamoto (1994) hypothesized that Anguilla japonica use the flow of the Kuroshio Current to transport themselves offshore before they turn to the south and migrate the rest of the distance to the spawning area. The behavior patterns of the eels in the present study are generally consistent with this hypothesis, but the effects of the tags on their behavior are difficult to estimate. Eels 6 and 8 clearly showed evidence of DVMs, but without additional data, how strong they attempted to swim horizontally is difficult to estimate without knowing the exact speed of the Kuroshio Current where they were located at night. The strongest current speeds in the core of the Kuroshio Current in the region where Eels
6 and 8 were located frequently reach $86.4 \mathrm{~km} \mathrm{~d}^{-1}$ or greater (up to $100 \mathrm{~cm} \mathrm{~s}^{-1}$ ) in the upper 200 to $300 \mathrm{~m}$, but speeds become slower at deeper depths (Zhu et al. 2001, Sekine 2002). If A. japonica swimming speeds are about 3.4 to $14.0 \mathrm{~km} \mathrm{~d}^{-1}$ and 2.2 to $15.1 \mathrm{~km}$ $\mathrm{d}^{-1}$, as suggested by Eels 6 and 8 in this study, these eels could have been able to swim out of the Kuroshio Current (almost $60 \mathrm{~km}$ wide at the release point on 21 December 2008) in about 4 to $27 \mathrm{~d}$, so they may have remained within the current to enhance their eastward transport.

It is difficult to determine what type of interaction there was between these eels and the powerful Kuroshio Current by using only the depth and temperature data from the PAT tags. While crossing the Kuroshio Current as larvae migrating to their juvenile growth habitats (Tsukamoto 1990), they could have imprinted on the characteristics of the current by using their well-developed olfactory sense (Tomoda \& Uematsu 1996), which might enable them to detect and stay within the Kuroshio Current to facilitate eastward movement during their early migration period. However, it is also possible that their swimming ability was weak when they entered the current and they did not attempt to swim out of it. This weakness may be reflected by the observation that Eels 6 and 7 appeared to dive to the bottom and remain there until their tags were prematurely released between 6 and $41 \mathrm{~d}$ after the eels were released.

A different migration pattern was observed for the Anguilla anguilla that have been tagged. Aarestrup et al. (2009) found that the route for the tagged eels in their study was on a nearly straight line from their growth habitat to their spawning site in the Sargasso Sea during the 4 to $126 \mathrm{~d}$ after release from western Ireland. They suggested this type of route could enable the eels to gain speed and increase travel efficiency by entering southand west-flowing currents such as the Canary Current (Aarestrup et al. 2009). In contrast, A. japonica from Japan, which have spawning sites to the south or southeast of their growth habitats, showed eastward movements at the beginning of their spawning migration. However, both studies suggested similar possible use of oceanic currents to gain speed and increase travel efficiency. Water currents are often a dominant feature of the open sea, and there is compelling evidence to indicate that the ocean currents play a major role in the life histories of a number of fish species (Metcalfe et al. 2002, 2006). Future research can attempt to determine whether Japanese eels use the Kuroshio Current for the early part of their spawning migration. 


\section{Swimming behavior}

The most significant findings of the present study were that Anguilla japonica showed a distinct pattern of DVM when they reached offshore waters that is similar to the DVM behavior of the 2 other anguillid species that have been studied, and that eels may try to stay within a preferred water temperature during the daytime, more so than at a particular depth. Eels 6 and 8 demonstrated a consistent pattern of DVM to depths below $500 \mathrm{~m}$ and experienced water temperature of about 4 to $10^{\circ} \mathrm{C}$ during the day, but swimming depth increased with time for Eel 6. Interestingly, Eel 6 eventually dove to a depth of $>1000$ m, but the water temperature it experienced remained almost the same, suggesting it may have been swimming down to a preferred temperature range during the day, but the depth of these temperatures was steadily changing. The isotherms slope rapidly deeper from the west and north sides of the Kuroshio Current to the east and south sides throughout the year in this region (Mizuno \& White 1983, Hanawa \& Hoshino 1988), which indicates the eel was steadily shifting from the north to the south side of the current. Suga et al. (1989) showed a temperature of $4^{\circ} \mathrm{C}$ at almost a depth of $1000 \mathrm{~m}$ in this area at $32^{\circ} \mathrm{N}$, $137^{\circ} \mathrm{E}$, and a temperature of 14 to $16^{\circ} \mathrm{C}$ at depths of 300 to $500 \mathrm{~m}$, which correspond to the daytime and nighttime depths and temperatures experienced during the last $8 \mathrm{~d}$ by Eel 6 . This eel also tended to swim at deeper depths at night, but it only experienced slightly cooler water temperatures because there is much less slope in the isotherms in the near-surface layer (Hanawa \& Hoshino 1988, Suga et al. 1989). Eel 8 showed a consistent pattern of daytime swimming depths between 100 to $800 \mathrm{~m}$ and experienced similar temperatures on most days. Eels 2 and 3 in January also showed evidence of DVM during the first parts of their tracks in the region south of Kyushu, and they experienced minimum daytime temperatures of about $6^{\circ} \mathrm{C}$, which are similar to those experienced by eels in November. These same general types of DVM patterns have also been observed in the previous studies that used PAT tags with $A$. dieffenbachii (Jellyman \& Tsukamoto 2002, 2005, 2010) and $A$. anguilla (Aarestrup et al. 2009), which suggests that DVM may be a common behavior in the spawning migration of anguillid eels.

The basic DVM patterns appear similar for migrating eels of the 3 temperate-zone species, but variations in depth of diel swimming and the associated water temperatures occur within and among species. Individual Anguilla dieffenbachii showed a variety of swimming patterns at different depths and they varied considerably in the temperatures experienced (Jellyman \& Tsukamoto 2002, 2005), which was similar to the variation observed in A. japonica in the present study. Some of this variation is probably due to the effects of the tags on the eels, but some is also due to the eels entering different water masses during their migration, e.g. inside or outside of the warm Kuroshio Current. Patterns of increasing swimming depths during the day or night have been observed in individual eels of the 3 species that have been studied, but the minimum temperatures experienced by these remained roughly similar (Eel 6 in this study, Aarestrup et al. 2009, Jellyman \& Tsukamoto 2010). This suggests that the temperature range may be more important than the depth during the day when eels move between different water masses. Some support for this may have been observed in 2 of the $A$. anguilla that migrated in slightly different directions towards the spawning area, with one swimming at a $>200 \mathrm{~m}$ depth during nighttime and mostly $>600 \mathrm{~m}$ during daytime, and the other at $<200 \mathrm{~m}$ and $<600 \mathrm{~m}$ in the night and day, respectively, but the temperatures they experienced appeared to be about the same (Aarestrup et al. 2009). Differences in temperatures experienced during the nighttime among the eels may be related to the 3 very different study areas. For example the Kuroshio Current had much warmer water temperatures in the upper $400 \mathrm{~m}$ than the waters to the north of New Zealand (Jellyman \& Tsukamoto 2010) and to the southeast of Ireland (Aarestrup et al. 2009). Eels 6 and 8 (primary nighttime temperatures: 14 to $22^{\circ} \mathrm{C}$, present study) showed deeper nighttime swimming depths, but experienced higher temperatures than both $A$. anguilla (average temperature: $11.7 \pm 0.5^{\circ} \mathrm{C}$, Aarestrup et al. 2009) and $A$. dieffenbachii (primary nighttime temperatures: 8 to $17^{\circ} \mathrm{C}$, Jellyman \& Tsukamoto 2010). During the daytime most of the eels of the 3 species showing DVM were swimming at depths between 500 and $900 \mathrm{~m}$, and their primary temperature ranges in the daytime (Eel 6: 4 to $10^{\circ} \mathrm{C}$; Eel 8: 4 to $10^{\circ} \mathrm{C}$, present study; A. anguilla: $10.1 \pm$ $0.9^{\circ} \mathrm{C}$, Aarestrup et al. 2009; A. dieffenbachii: 5 to $8^{\circ} \mathrm{C}$, Jellyman \& Tsukamoto 2010) were not as different as those during the nighttime.

Although DVM of marine organisms has been typically thought to be for avoiding predators (Stich \& Lampert 1981, Scheuerell \& Schindler 2003) and for maximizing foraging and growth (Schabetsberger et al. 2000), these migrations in eels may be made, in part, for reproductive reasons (Jellyman \& Tsukamoto 2005, 2010, Aarestrup et al. 2009). Aare- 
strup et al. (2009) suggested that the daily ascent into shallower warm water is to maintain high metabolism and the descent to deeper waters is to experience lower temperatures for delaying gonad development until the eels reach the spawning area. Jellyman \& Tsukamoto (2010) also suggested that while warm temperatures are necessary to achieve full maturity, continued exposure to cool temperatures inhibits maturation. Indeed, recent laboratory experiments showed that maturation of anguillid eels is induced by high water temperature $\left(20^{\circ} \mathrm{C}\right)$ and swimming itself (Sato et al. 2006, Palstra et al. 2007) and could not be induced at a lower temperature $\left(10^{\circ} \mathrm{C}\right.$, Sato et al. 2006).

In addition to possible temperature factors, the swimming depths of DVMs during the nighttime could be influenced by the typical swimming depths of predators. Although the water temperatures experienced by eels during the nighttime were variable among the 3 species, the general range of swimming depths were similar (Anguilla japonica: 100 to $499 \mathrm{~m}$, present study; A. anguilla: $282 \pm 138 \mathrm{~m}$, Aarestrup et al. 2009; A. dieffenbachii: 100 to $400 \mathrm{~m}$, Jellyman \& Tsukamoto 2010). Typical nighttime swimming depths of predator fishes like tuna, sharks and swordfish were observed to be shallower than $100 \mathrm{~m}$ (Wilson et al. 2005, Weng et al. 2007, Abascal et al. 2010). Therefore, migrating anguillid eels may typically swim between 100 to $499 \mathrm{~m}$ during the nighttime to avoid encountering such predators. It is clear, however, that the DVMs of anguillid eels are probably not related to feeding, because of the degeneration of the gastrointestinal tract, which has been observed in A. japonica in spawning condition (Tsukamoto et al. 2011), and a lack of evidence of feeding during their spawning migration using stable isotope analyses (Chow et al. 2010).

\section{Predation pressure}

For Eel 3, the sudden change in water temperature $4 \mathrm{~d}$ after its release from 5.8 to $18.8^{\circ} \mathrm{C}$ up to 7.6 to $26.4^{\circ} \mathrm{C}$ until the tag ascended to the surface on Day 12 suggests that this eel was eaten by a predator. Other evidence supportive of predation is that no light intensity data were recorded during the deployed period even after the tag recorded being at depths shallow enough to detect light. In the study area, potential predators of eels such as white sharks Charcharodon carcharias and Pacific bluefin tuna Thunnus orientalis are present in winter (Nakaya 1994, Kitagawa et al. 2002). Acoustic transmitters have revealed stomach temperatures of white sharks and bluefin tuna to be 23.4 to $27.6^{\circ} \mathrm{C}$ (Goldman 1997) and 10 to $30^{\circ} \mathrm{C}$ (Carey et al. 1984), respectively. The warmer temperature experienced by Eel 3 suggests that this eel was eaten by a shark at $4 \mathrm{~d}$ after the release and the PAT tag measured and recorded the temperature inside the shark's stomach. Thereafter, the shark regurgitated or evacuated the tag, which then floated to the surface and successfully transmitted its data. This happened in a previous study when a transmitter inserted in a shark stomach was regurgitated after $17 \mathrm{~d}$ (Goldman 1997). This implies that eels with a surgically attached external tag may be vulnerable to predation as a result of their bleeding after the tag was attached. This could provide an olfactory cue to predators, or the extra movement of the attached tag may make them more visible or less able to avoid predation.

\section{Advantages and disadvantages of PAT tags}

A possible negative effect of PAT tags on the swimming behavior of smaller eels was observed in the present study, and the buoyancy of the tags was modified after the results from the first 3 eels were obtained in January. This subsequent modification appeared to improve the ability of the eels to show DVM in November. The studies with Anguilla anguilla and large A. dieffenbachii that used PAT tags also indicated that the effect of dragging a tag could inhibit the swimming speed of the eels (Jellyman \& Tsukamoto 2002, Aarestrup et al. 2009). By comparing our results in January and November 2008, we noted slight differences in swimming depths that suggested, in January, the tags had an adverse effect on the eels as they provided more buoyancy. Eels in January, especially Eel 1 that was the smallest eel in this study, swam mostly in the upper layer between 0 to $100 \mathrm{~m}$, whereas the eels in November shifted to much deeper depths and showed clear bimodal distributions between day and night (Figs. $4 \& 6$ ). These observations imply that eels were weakened and swam near the surface layer because of the flotation and drag effects of the tags in January, and that our modification of the attachment technique by adding a weight to adjust the tag to neutral buoyancy in November may have been effective. Indeed, the tracking periods in November were significantly longer than those of January. Further modifications of the attachment method to reduce float and drag effects are needed, and smaller sized PAT tags would also help reduce the apparent problems caused by these tags. 


\section{CONCLUSIONS}

The present study obtained the first information about the offshore spawning migration behavior of Anguilla japonica. The longest tracking period was for $39 \mathrm{~d}$ after release and 2 eels showed a pattern of DVM in November. The bimodal depth data of 2 eels in January also implied a pattern of DVM. The November eels mostly swam at depths of 100 to $500 \mathrm{~m}$ during the nighttime and 500 to $800 \mathrm{~m}$ during the daytime. The deepest depths that the eels reached during the day may be related to temperature, because the daytime temperatures they experienced were less variable than their swimming depths, which may have been caused by the eels swimming downward to find their preferred range of water temperature. The results from some of the tagged eels, however, suggested there were some technical problems with the use of PAT tags with small eels due to the attachment methods, the effects of the flotation and drag caused by the tags and the possibility that the tags could increase the chance for predation. Improved tracking methods that use modified or smaller PAT tags are needed for studies on smaller anguillid eel species to be able to learn more about their spawning migrations.

Acknowledgements. We are grateful to H. Harada and A. Okamura for the providing the eels used in this study. We also thank the captain and crew of the RV 'Tansei Maru', M. Kyoso, T. Inagaki, M. Oya, B. Ai, M. Kuroki, S. Hagihara, S, Miyazaki and H. Matsuo for field assistance, and R. Sudo for assistance in the tagging test. Thanks are also extended to members of the IRAGO Institute and members of the Fisheries Laboratory of the Graduate School of Agricultural and Life Sciences, The University of Tokyo, for assistance in the tagging test. We appreciate the comments and suggestions by K. Yokouchi and T. Kitagawa that helped improve the paper. We also appreciate the use of the Maptool program for analysis and graphics in this paper (Maptool is a product of SEATURTLE.ORG; information is available at www.seaturtle.org). A part of this research was supported by Grantin-Aid for JSPS Fellows (09J06070).

\section{LITERATURE CITED}

Aarestrup K, Okland F, Hansen MM, Righton D and others (2009) Oceanic spawning migration of the European eel (Anguilla anguilla). Science 325:1660

Abascal FJ, Mejuto J, Quintans M, Ramos-Cartelle A (2010) Horizontal and vertical movements of swordfish in the southeast Pacific. ICES J Mar Sci 67:466-474

> Aoyama J, Hissmann K, Yoshinaga T, Sasai S, Uto T, Ueda H (1999) Swimming depth of migrating silver eels Anguilla japonica released at seamounts of the West Mariana Ridge, their estimated spawning sites. Mar Ecol Prog Ser 186:265-269
Aoyama J, Sasai S, Miller MJ, Shinoda A, Nakamura A, Kawazu K, Tsukamoto K (2002) A preliminary study of the movements of yellow and silver eels, Anguilla japonica, in the estuary of the Fukui River, Japan, as revealed by acoustic tracking. Hydrobiologia 470:31-36

Block BA, Dewar H, Williams T, Prince ED, Farwell C, Fudge D (1998) Archival tagging of Atlantic bluefin tuna (Thunnus thynnus thynnus). Mar Technol Soc J 32:37-46

Block BA, Teo SLH, Walli A, Boustany A and others (2005) Electronic tagging and population structure of Atlantic bluefin tuna. Nature 434:1121-1127

Carey FG, Kanwisher JW, Stevens ED (1984) Bluefin tuna (Thunnus thynnus) warm their viscera during digestion. J Exp Biol 109:1-20

> Chow S, Kurogi H, Mochioka N, Kaji S, Okazaki M, Tsukamoto K (2009) Discovery of mature freshwater eels in the open ocean. Fish Sci 75:257-259

Chow S, Kurogi H, Katayama S, Ambe D and others (2010) Japanese eel Anguilla japonica do not assimilate nutrition during the oceanic spawning migration: evidence from stable isotope analysis. Mar Ecol Prog Ser 402: 233-238

> Ducet N, Le Traon PY, Reverdin G (2000) Global high resolution mapping of ocean circulation from Topex/ Poseidon and ERS-1 and -2. J Geophys Res 105(C8): 19477-19498

Goldman KJ (1997) Regulation of body temperature in the white shark, Carcharodon carcharias. J Comp Physiol B 167:423-429

> Hanawa K, Hoshino I (1988) Temperature structure and mixed layer in the Kuroshio Region over the Izu Ridge. J Mar Res 46:683-700

- Ichikawa H, Beardsley RC (2002) The current system in the Yellow and East China Seas. J Oceanogr 58:77-92

Jellyman D, Tsukamoto K (2002) First use of archival transmitters to track migrating freshwater eels Anguilla dieffenbachii at sea. Mar Ecol Prog Ser 233:207-215

> Jellyman D, Tsukamoto K (2005) Swimming depths of offshore migrating longfin eels Anguilla dieffenbachii. Mar Ecol Prog Ser 286:261-267

- Jellyman D, Tsukamoto K (2010) Vertical migrations may control maturation in migrating female Anguilla dieffenbachii. Mar Ecol Prog Ser 404:241-247

Kitagawa T, Nakata H, Kimura S, Sugimoto T, Yamada H (2002) Differences in vertical distribution and movement of Pacific bluefin tuna (Thunnus thynnus orientalis) among areas: the East China Sea, the Sea of Japan and the western North Pacific. Mar Freshw Res 53:245-252

Kotake A, Arai T, Ozawa T, Nojima S, Miller MJ, Tsukamoto $\mathrm{K}$ (2003) Variation in migratory history of Japanese eels, Anguilla japonica, collected in coastal waters of the Amakusa Islands, Japan, inferred from otolith Sr/Ca ratios. Mar Biol 142:849-854

Matsui I (1972) Eel biology. Biological Study Tokyo, Kouseisha-Kouseikaku

$>$ McCleave JD, Arnold GP (1999) Movements of yellow- and silver-phase European eels (Anguilla anguilla L.) tracked in the western North Sea. ICES J Mar Sci 56:510-536

Metcalfe JD, Arnold GP, McDowall RA (2002) Migration. In: Hart PJB, Reynolds JD (eds) Handbook of fish biology and fisheries, Vol I. Blackwell Scientific, Oxford, p 175-199

> Metcalfe JD, Hunter E, Buckley AA (2006) The migratory behaviour of North Sea plaice: currents, clocks and clues. Mar Freshw Behav Physiol 39:25-36 
Mizuno K, White WB (1983) Annual and interannual variability in the Kuroshio Current system. J Phys Oceanogr 13:1847-1867

Nakaya K (1994) Distribution of white shark in Japanese waters. Fish Sci 60:515-518

Okamura A, Yamada Y, Yokouchi K, Horie N and others (2007) A silvering index for the Japanese eel Anguilla japonica. Environ Biol Fishes 80:77-89

Palstra A, Curiel D, Fekkes M, de Bakker M, Szekely C, van Ginneken V, van den Thillart G (2007) Swimming stimulates oocyte development in European eel. Aquaculture 270:321-332

Sasai S, Aoyama J, Watanabe S, Kaneko T, Miller MJ, Tsukamoto K (2001) Occurrence of migrating silver eels Anguilla japonica in the East China Sea. Mar Ecol Prog Ser 212:305-310

Sato N, Kawazoe I, Suzuki Y, Aida K (2006) Effects of temperature on vitellogenesis in Japanese eel Anguilla japonica. Fish Sci 72:961-966

Schabetsberger R, Brodeur RD, Ciannelli L, Napp JM, Swartzman GL (2000) Diel vertical migration and interaction of zooplankton and juvenile walleye pollock (Theragra chalcogramma) at a frontal region near the Pribilof Islands, Bering Sea. ICES J Mar Sci 57:1283-1295

Scheuerell MD, Schindler DE (2003) Diel vertical migration by juvenile sockeye salmon: empirical evidence for the antipredation window. Ecology 84:1713-1720

Schmidt J (1922) The breeding places of the eel. Philos Trans R Soc 211:179-208

Sekine Y (2002) Geostrophic velocity of the Kuroshio south of Japan. Bull Fac Bioresour Mie Univ 29:75-86

Stich HB, Lampert W (1981) Predator evasion as an explanation of diurnal vertical migration by zooplankton. Nature 293:396-398

Suga T, Hanawa K, Toba Y (1989) Subtropical mode water in the $137^{\circ}$ E section. J Phys Oceanogr 19:1605-1618

Tesch FW (1978) Telemetric observations on the spawning migration of the eel (Anguilla anguilla) west of the European continental shelf. Environ Biol Fishes 3:203-209

Tesch FW (1989) Changes in swimming depth and direction of silver eels (Anguilla anguiila L.) from the continental

Editorial responsibility: Ivan Nagelkerken,

Nijmegen, The Netherlands shelf to the deep sea. Aquat Living Resour 2:9-20

Tesch FW (2003) The eel. Blackwell Science, Oxford

- Tomoda H, Uematsu K (1996) Morphogenesis of the brain in larval and juvenile Japanese eels, Anguilla japonica. Brain Behav Evol 47:33-41

Tsukamoto K (1990) Recruitment mechanism of the eel, Anguilla japonica, to the Japanese coast. J Fish Biol 36: 659-671

Tsukamoto K (1992) Discovery of the spawning area for the Japanese eel. Nature 356:789-791

Tsukamoto K (1994) Origin of diadromous fishes and mechanism of migration. In: Goto A, Tsukamoto K, Maekawa $\mathrm{K}$ (eds) Freshwater fishes migrating between river and the sea.Tokai University Press, Tokyo, p 42-58

Tsukamoto K (2006) Spawning of eels near a seamount. Nature 439:929

> Tsukamoto K (2009) Oceanic migration and spawning of anguillid eels. J Fish Biol 74:1833-1852

> Tsukamoto K, Otake T, Mochioka N, Lee TW and others (2003) Seamounts, new moon and eel spawning: the search for the spawning site of the Japanese eel. Environ Biol Fishes 66:221-229

> Tsukamoto K, Chow S, Otake T, Kurogi H and others (2011) Oceanic spawning ecology of freshwater eels in the western North Pacific. Nat Commun 2:179 doi:10.1038/ ncomms1174

> Weng KC, O'Sullivan JB, Lowe CG, Winkler CE, Dewar H, Block BA (2007) Movements, behavior and habitat preferences of juvenile white sharks Carcharodon carcharias in the eastern Pacific. Mar Ecol Prog Ser 338:211-224

Wilson SG, Lutcavage ME, Brill RW, Genovese MP, Cooper AB, Everly AW (2005) Movements of bluefin tuna (Thunnus thynnus) in the northwestern Atlantic Ocean recorded by pop-up satellite archival tags. Mar Biol 146: 409-423

Yokose H (2008) Geological approach to the spawning sites of the Japanese eel. Kaiyo Monthly 48(Spec Issue):45-58

> Zhu XH, Kaneko A, Saito T, Gohda N (2001) Kuroshio stream path variation and its associated velocity structures south of Shikoku, Japan. Geophys Res Lett 28: 4615-4618

Submitted: December 10, 2010; Accepted: June 17, 2011

Proofs received from author(s): August 27, 2011 